\title{
Effects of Indol-3-Acetic Acid on the biology of Galleria mellonella and its endoparasitoid Pimpla turionellae
}

\author{
Fevzi Uçkan ${ }^{1, *}$, Rabia Özbek¹, Ekrem Ergin²
}

\begin{abstract}
1 Department of Biology, Faculty of Science and Literature, Kocaeli University, Kocaeli, 41380, TURKEY
2 Nursing School, Gülhane Military Medical Academy, Ankara, 06018, TURKEY (e-mails: ozbekrabia@gmail.com, ekremxergin@hotmail.com)

* Corresponding author: fevzi.uckan@kocaeli.edu.tr
\end{abstract}

\begin{abstract}
The effects of indol-3-acetic acid (IAA) were investigated on biological parameters of Galleria mellonella (Linnaeus, 1758) (Lepidoptera: Pyralidae) and its endoparasitoid Pimpla turionellae (Linnaeus 1758) (Hymenoptera: Ichneumonidae) reared on hosts treated with 50 to $10,000 \mathrm{ppm}$ of IAA in their diet. Percent fecundity of first generation of G. mellonella females increased by $12 \%$ at $50 \mathrm{ppm}$ whereas the most effective decrease, by $>33 \%$, was observed at $5,000 \mathrm{ppm}$. Percent fertility decreased by $>20 \%$ at $1,000 \mathrm{ppm}$. All treatments displayed $\pm 5 \%$ variations when compared to controls except for a $>20 \%$ increase in corrected percent sterility at $1,000 \mathrm{ppm}$. The results did not reveal any considerable effect of IAA on egg hatching, larval and pupal developmental, or adult emergence times. The most striking effect observed was a decline in second generation pupal developmental time by $>47 \%$ at 1,000 and $10,000 \mathrm{ppm}$. No dose-wise alterations were observed in adult longevity, weight, size and female sex ratio of G. mellonella. Treatment with IAA caused a slight prolongation in adult emergence and decrease in longevity of $P$. turionellae reared on hosts; longevity of wasps declined by $>27 \%$ at higher doses. Neither wasp size nor weight displayed significant changes upon IAA treatment.
\end{abstract}

KEY WORDS: Biology, Galleria mellonella, Indole-3-acetic acid, Pimpla turionellae.

\section{INTRODUCTION}

Synthetic chemicals acting as plant growth regulators (PGRs) have been widely used to obtain high levels of agricultural productivity. However, these chemicals not only affect plant growth and development, but they also negatively affect the development, survival, longevity, reproductive potential, hemocytes, and hemolymph metabolites of insects and other animals (AHMED et al, 2003; PAULSON et al., 2005; GUPTA et al., 2009; UÇKAN et al., 2008, UÇKAN et al., 2011a, b; ALTUNTAŞ et al., 2012). The toxic effects of PGRs, including indole-3-acetic acid (IAA), on the development and reproductive potential of the pest species, Bactrocera cucurbitae (COQUILLETT, 1849) were investigated and the authors suggested that these eco-friendly compounds are promising candidates to replace pesticides in Integrated Pest Management (IPM) programs of economically important pest insect (KAUR \& RUP, 2002). GUPTA et al. (2009) also reported that gibberellic acid $\left(\mathrm{GA}_{3}\right)$ and siapton (an amino acid based plant growth stimulant) caused an increase in the larval period of the hairy caterpillar, Spilarctia obliqua (WALKER, 1855) at high doses. However, the overall effects of PGRs on insects still need to be clarified to improve the strategies for pest control and to know what kind of effects these compounds have especially on natural enemies of pest species. For example, UÇKAN et al. (2008; 2011a) demonstrated that egg to adult developmental time of the wasp species, Apanteles galleriae (WILKINSON, 1932) reared on Achoria grisella (FABRICIUS, 1794) larvae exposed to high doses of $\mathrm{GA}_{3}$ and IAA increased by $40 \%$ and $30 \%$, respectively when wasps were reared on larvae exposed to higher doses of the PGRs. Furthermore, the adult longevity of $A$. galleriae decreased by $>50 \%$ when wasps were reared on IAA- or $\mathrm{GA}_{3}$-treated hosts (UÇKAN et 
al., 2008, 2011a). Recently, UÇKAN et al. (2011b) also stated that higher doses of $\mathrm{GA}_{3}$ negatively affected the adult longevity of the wasp species, Pimpla turionellae (Linnaeus, 1758) (Hymenoptera: Ichneumonidae). A decrease in length was also apparent at most of the treatment levels. Their results also revealed that hemolymph carbohydrate at most of the dose levels, and lipid at all decreased in host larvae upon exposure to GA $_{3}$. KAUR \& KAUR (2013) reported that the braconid parasitoid, Bracon hebetor (SAY, 1836) reared on coumarin-treated host, Spodoptera litura (FABRICIUS, 1775) displayed declines in reproductive potential, female life span, and egg hatching with an extended developmental period at higher concentrations. PRADO \& FRANK (2013) also showed that PGRs had adverse effects on parasitoid fitness and caused a decrease in parasitism incidence. Evidence from our and other earlier studies strongly supports the idea that exposure to PGRs via the host diet influences physiological and biochemical mechanisms and plays roles in maintaining survival activities of both pests and their natural enemies.

Many advantages of Galleria mellonella (LinNAEUS, 1758) (Lepidoptera: Pyralidae) caterpillars have convinced an increasing number of researchers to favor this species as a powerful, reliable, and proven model system to evaluate the effects of toxic substances on both target species and non-target beneficial ones (SAK et al., 2006; BÜYÜKGÜZEL et al., 2007; ERGIN et al., 2007; UÇKAN et al., 2008; 2011a, b; ALTUNTAȘ et al., 2012). Larvae of the host species are serious pests in beehives. They damage the combs by boring into the hive and leaving silk-lined tunnels or galleries (SANFORD 1987). The solitary idiobiont pupal endoparasitoid $P$. turionellae is utilized for biological control of a number of lepidopteran pest species involving G. mellonella (KANSU \& UĞUR 1984, FISHER, 1987). Upon paralyzation by the wasp species at the time of oviposition (HAESELBARTH 1979), the paralyzed host provides food and a living space for larval parasitoids and sometimes food for the adult parasitoid (SLANSKY, 1986). Some host species of $P$. turionellae also feed on plants and the adult wasps feed on plant nectar and host pupae in nature. Therefore, the accumulation of environmental pollutants and transmission of these compounds to wasps by both feeding in/ on a host directly and by feeding on plant nectar, indirectly, are likely to occur (SAK et al. 2006, ERGIN et al. 2007). Thus, the present work was carried out to determine IAA-induced changes in reproductive potential of first generation $\left(\mathrm{F}_{1}\right)$ of $G$. mellonella and egg hatching time, larval and pupal developmental time, adult emergence time, adult longevity, female sex ratio, adult weight and size of second generation $\left(\mathrm{F}_{2}\right)$ of $G$. mellonella, as well as immature developmental time, adult longevity, adult weight and size of $P$. turionellae.

\section{MATERIAL AND METHODS}

\section{Parasitoid and Host Rearing}

Laboratory colonies of the host, G. mellonella and the parasitoid, P. turionellae were established from adults reared at $25 \pm 5^{\circ} \mathrm{C}, 60 \pm 5 \% \mathrm{RH}$, and with a photoperiod of 12: 12 (L:D) h in our laboratory in Kocaeli University, Turkey. Larvae of G. mellonella were maintained by feeding the insects with a diet described by BRONSKILL (1961) and modified by SAK et al. (2006). A piece of honey comb was also added for egg deposition and feeding of the newly hatched larvae. P. turionellae were mass reared on the pupae of the host, G. mellonella in cages $(25 \times 25$ x $25 \mathrm{~cm}$ ). Adults of parasitoids were fed a 30\% (wt: vol) honey solution and provided with host pupae (four pupae for every 10 female wasps once every 3 d) (SAK et al., 2006).

\section{Bioassays}

An individual mating pair of the host, 1- or 2-day-old G. mellonella was placed in 1-L jars containing $2 \mathrm{~g}$ honeycomb to provide a mating and oviposition substrate. Adults were removed from the jars on the seventh day. Newly hatched first generation $\left(\mathrm{F}_{1}\right)$ larvae of $G$. mellonella in 
jars were exposed to $10 \mathrm{~g}$ of the host diet (SAK et al., 2006) treated with 50, 500, 1,000, 5,000 and 10,000 ppm IAA (Merck 10 g, Darmstadt, Germany) homogenized with doses in separate jars. Larvae reared on IAA-free diet were controls. Both experimental and control group diets were replenished daily.

Last instars of $\mathrm{F}_{1}$ of $G$. mellonella $(0.18 \pm 0.02$ g) were randomly selected in groups of five, transferred to sterile Petri dishes, and controlled every day until adult emergence. To determine the total number of eggs laid per female, percent fecundity, percent fertility, and corrected percent sterility of $\mathrm{F}_{1}$ and egg hatching, larval, and pupal developmental time, adult emergence time, adult longevity, sex ratio, adult weight and size of second generation $\left(\mathrm{F}_{2}\right)$ of $G$. mellonella, an individual mating pair of $\mathrm{F}_{1}$ adults of $G$. mellonella $(\mathrm{n}=30)$ was placed into $210 \mathrm{ml}$ cups. A piece of paper was placed into each cup as a deposition substrate then cups were covered with gauze to allow air exchange. G. mellonella females were allowed to deposit eggs on papers. The papers on which eggs had been oviposited were changed daily and the number of eggs on them was counted every two days for $16 \mathrm{~d}$. The data were tabulated for the total number of eggs deposited by each female, percent fecundity, and percent fertility in experimental and control groups. Corrected percent fertility was calculated according to KAUR \& RUP (2002) by applying the following formula:

Corrected percent sterility $=$

$\frac{\% \text { Fertility in control }-\% \text { Fertility in treatment }}{\% \text { Fertility in control }} \times 100$

From each treatment and control group five $\mathrm{F}_{2}$ eggs were randomly selected and individually transferred to sterile Petri dishes including $2 \mathrm{~g}$ of host diet treated with different doses of IAA and observed daily until egg hatching, and the time between egg laying and hatching recorded as egg hatching time. Diet was replenished daily until larvae pupated and the time between egg hatching and pupation recorded as larval developmental time. The pupated individuals were observed until adult emergence, and pupal developmental times were recorded. Then, all Petri dishes were observed at 24-h intervals until all individuals died, and the time between adult emergence and death were recorded as adult longevity. Female sex ratio and adult weight of the newly emerged adults were also assessed. Adult body size of $G$. mellonella was determined by measuring the length from head to the tip of the abdomen using an Olympus SZ51 (Olympus, center Valley, PA) stereo dissecting microscope equipped with a calibrated eyepiece micrometer.

In a parallel set of experiments, upon molting to the last stage, larvae $(0.18 \pm 0.02 \mathrm{~g})$ of $G$. mellonella $\mathrm{F}_{1}$ were randomly selected from the jars and transferred in groups of five to sterile Petri dishes and controlled every day until larvae pupated. Then, parasitization was performed on day 1 or 2 of the host pupae by exposing an individual host pupa to an individual 10to 20-d-old wasp female. Parasitized pupae were observed until adult emergence. The time required for completion of development from egg deposition to adult eclosion of parasitoids was recorded as immature developmental time. Newly emerged female and male parasitoid weight from each treatment and control group was recorded as adult weight. Then, individual mating pairs of five for each experimental and control group were placed in a $210 \mathrm{ml}$ cup containing a cotton ball saturated in a $30 \%$ (wt: vol) honey solution. Cups were covered with a mesh cloth and food was replenished every day. Parasitoids were observed at 24-h intervals until all parasitoids died and adult longevity was recorded. Adult body size of $P$. turionellae was also determined by the method described above for host species.

\section{Statistical Analysis}

The experiments were repeated three times with specimens taken from different populations at different times. Means were compared using one-way analysis of variance (ANOVA) of SPSS V.18 for Windows. Means were subjected to Tukey's Honestly Significant Difference (HSD) 
Table 1

IAA-related changes in total number of eggs/female, percent fecundity, percent fertility and corrected percent sterility of G. mellonella.

\begin{tabular}{|c|c|c|c|c|}
\hline IAA (ppm) & $\begin{array}{c}\text { Total no. of eggs/female } \\
\text { Mean } \pm \mathrm{SE}^{\mathrm{b}}\end{array}$ & $\begin{array}{c}\text { Percent fecundity } \\
\text { Mean }^{\mathrm{a}} \pm \mathrm{SE}^{\mathrm{b}}\end{array}$ & $\begin{array}{c}\text { Percent fertility } \\
\text { Mean }^{\mathrm{a}} \pm \mathrm{SE}^{\mathrm{b}}\end{array}$ & $\begin{array}{c}\text { Corrected percent sterility } \\
\text { Mean }^{\mathrm{a}} \pm \mathrm{SE}^{\mathrm{b}}\end{array}$ \\
\hline 0 & $699.53 \pm 77.98 \mathrm{a}$ & $100.00 \pm 0.00 \mathrm{ab}$ & $88.04 \pm 2.00 \mathrm{a}$ & - \\
50 & $784.67 \pm 82.85 \mathrm{a}$ & $112.17 \pm 11.84 \mathrm{~b}$ & $92.75 \pm 0.89 \mathrm{a}$ & $-5.35 \pm 1.01 \mathrm{a}$ \\
500 & $581.67 \pm 80.45 \mathrm{a}$ & $83.15 \pm 11.50 \mathrm{ab}$ & $89.20 \pm 1.42 \mathrm{a}$ & $-1.32 \pm 1.61 \mathrm{a}$ \\
1,000 & $571.53 \pm 84.62 \mathrm{a}$ & $89.47 \pm 12.18 \mathrm{ab}$ & $70.07 \pm 8.18 \mathrm{~b}$ & $20.41 \pm 9.29 \mathrm{~b}$ \\
5,000 & $465.33 \pm 74.05 \mathrm{a}$ & $66.52 \pm 10.59 \mathrm{a}$ & $83.25 \pm 4.01 \mathrm{ab}$ & $5.45 \pm 4.56 \mathrm{ab}$ \\
10,000 & $546.87 \pm 66.14 \mathrm{a}$ & $78.18 \pm 9.46 \mathrm{ab}$ & $87.57 \pm 2.74 \mathrm{a}$ & $0.53 \pm 3.12 \mathrm{a}$ \\
\hline
\end{tabular}

a Means within each column followed by the same letter are not significantly different $(\mathrm{P}>0.05)$.

${ }^{\mathrm{b}}$ Average of 15 individuals per treatment.

test when variances were homogenous, but Tamhane T2 tests otherwise were used to assess the significance of the effects of IAA doses $(\mathrm{P}<$ $0.05)$.

\section{RESULTS}

The total number of eggs laid by a single host female fed on IAA-free diet was $699.53 \pm 77.98$. Treatment of IAA did not considerably affect the number of eggs laid by $G$. mellonella regardless of the dose tested $(\mathrm{F}=2.164 ; \mathrm{df}=5,84 ; \mathrm{P}=$ 0.066 ). The number of eggs laid per female did decrease at all dose levels except $50 \mathrm{ppm}$, however the differences were not significant with respect to controls (Table 1). The percent fecundity of the control group was assumed as $100 \%$ in order to determine the relative percent fecundity of assays. The lack of a decrease in total number of eggs at $50 \mathrm{ppm}$ of IAA treatment also led to an increase in percent fecundity and fertility where fecundity was increased to $112.17 \pm 11.84 \%$ with $92.75 \pm 0.89 \%$ fertility at the lowest concentration. This trend was not the same for other dose treatments with a fluctuation among doses, reduced significantly at only 5,000 ppm for percent fecundity $(\mathrm{F}=2.528 ; \mathrm{df}=4,70$; $\mathrm{P}=0.035$ ) (Table 1). Percent fertility decreased significantly only at $1,000 \mathrm{ppm}(\mathrm{F}=3.940 ; \mathrm{df}=$ $5,84 ; \mathrm{P}=0.003)$ with a considerable increase in corrected percent sterility ( $\mathrm{F}=4.146$; df: 4, 70; $\mathrm{P}$ $=0.005$ ) reaching $20.41 \pm 9.29 \%$ when compared to other doses (Table 1).

Exposure to IAA in host diet resulted in an increase in egg hatching time of $\mathrm{F}_{2}$ females of $G$. mellonella only at 1,000 and $10,000 \mathrm{ppm}$ doses $(\mathrm{F}=19.731 ; \mathrm{df}=5,264 ; \mathrm{P}=0.00)$ (Table 2). Similarly, larval developmental time increased $(\mathrm{F}=29.916 ; \mathrm{df}=5,264 ; \mathrm{P}=0.00)$ at 500 and $5,000 \mathrm{ppm}$ with respect to control (Table 2). However, pupal developmental time of $G$. mellonella decreased ( $\mathrm{F}=86.128$; df $=5,264$; $\mathrm{P}=0.00)$ by $>47 \%$ at 1,000 and $10,000 \mathrm{ppm}$ (Table 2). On other hand, adult emergence time fluctuated among treatments $(\mathrm{F}=48.676$; $\mathrm{df}=$ $5,264 ; \mathrm{P}=0.00)$ and significantly decreased at 1,000 and $10,000 \mathrm{ppm}$ and increased at 50 and $500 \mathrm{ppm}$ with respect to controls (Table 2). 


\section{TABLE 2}

IAA-related changes in egg hatching, larval, pupal developmental and adult emergence times (day) of $G$. mellonella.

\begin{tabular}{|c|c|c|c|c|}
\hline IAA (ppm) & $\begin{array}{c}\text { Egg hatching time } \\
\text { Mean }^{\mathrm{a}} \pm \mathrm{SE}^{\mathrm{b}}\end{array}$ & $\begin{array}{c}\text { Larval developmental time } \\
\text { Mean }^{\mathrm{a}} \pm \mathrm{SE}^{\mathrm{b}}\end{array}$ & $\begin{array}{c}\text { Pupal developmental time } \\
\text { Mean }^{\mathrm{a}} \pm \mathrm{SE}^{\mathrm{b}}\end{array}$ & $\begin{array}{c}\text { Adult emergence time } \\
\text { Mean }^{\mathrm{a}} \pm \mathrm{SE}^{\mathrm{b}}\end{array}$ \\
\hline 0 & $10.16 \pm 0.12 \mathrm{a}$ & $44.13 \pm 0.43 \mathrm{a}$ & $13.18 \pm 0.27 \mathrm{a}$ & $67.47 \pm 0.40 \mathrm{~b}$ \\
50 & $9.96 \pm 0.07 \mathrm{a}$ & $45.18 \pm 0.20 \mathrm{ab}$ & $14.78 \pm 0.79 \mathrm{a}$ & $69.91 \pm 0.74 \mathrm{c}$ \\
500 & $10.16 \pm 0.05 \mathrm{a}$ & $46.93 \pm 0.20 \mathrm{c}$ & $13.31 \pm 0.26 \mathrm{a}$ & $70.40 \pm 0.30 \mathrm{c}$ \\
1,000 & $12.84 \pm 0.68 \mathrm{~b}$ & $43.00 \pm 0.30 \mathrm{a}$ & $6.80 \pm 0.29 \mathrm{~b}$ & $62.78 \pm 0.87 \mathrm{a}$ \\
5,000 & $10.20 \pm 0.08 \mathrm{a}$ & $45.62 \pm 0.23 \mathrm{~b}$ & $13.22 \pm 0.29 \mathrm{a}$ & $69.04 \pm 0.32 \mathrm{bc}$ \\
10,000 & $12.27 \pm 0.10 \mathrm{~b}$ & $43.27 \pm 0.22 \mathrm{a}$ & $6.36 \pm 0.16 \mathrm{~b}$ & $61.89 \pm 0.15 \mathrm{a}$ \\
\hline
\end{tabular}

${ }^{a}$ Means within each column followed by the same letter are not significantly different $(\mathrm{P}>0.05)$.

b Average of 45 individuals per treatment.

IAA-treated $G$. mellonella $\mathrm{F}_{2}$ adults lived for shorter times than controls at all doses tested, however this decline in longevity of adults was not significant $(\mathrm{F}=2.196 ; \mathrm{df}=5,264 ; \mathrm{P}=$ 0.055). This trend was also similar in the female sex ratio of adults, showing variations among doses but the ratio did not differ significantly ( $\mathrm{F}$ $=2.137 ; \mathrm{df}=5,12 ; \mathrm{P}=0.130)$ upon exposure to different doses of IAA (Table 3). On the other hand, adult weight of $G$. mellonella significantly decreased $(\mathrm{F}=4.538 ; \mathrm{df}=5,264$; $\mathrm{P}=0.001)$ at $500 \mathrm{ppm}$ with respect to controls (Table 3). Adult size of G. mellonella did not differ significantly when compared to controls, but it did increase at $10,000 \mathrm{ppm}$ with respect to 500 and 5,000 ppm $(\mathrm{F}=3.610 ; \mathrm{df}=5,264 ; \mathrm{P}=$ 0.004) (Table 3).

Immature developmental time of $P$. turionellae females reared on G. mellonella pupae exposed to different doses of IAA was not significantly different to that of female parasitoids reared on untreated hosts $(\mathrm{F}=1.418 ; \mathrm{df}=5,174 ; \mathrm{P}=$ 0.198) (Table 4). However, males at $1,000 \mathrm{ppm}$ $(\mathrm{F}=4.472 ; \mathrm{df}=5,174 ; \mathrm{P}=0.001)$ completed their immature development later than did those in control and other experimental groups. Wasp development from egg to adult at $25^{\circ} \mathrm{C}$ normally required 13-23 $\mathrm{d}$ in the control group. Treatment with IAA increased immature developmental time of parasitoids, especially at doses $>500$ ppm $(\mathrm{F}=4.259 ; \mathrm{df}=5,354 ; \mathrm{P}=0.001)$ and parasitoids reared on hosts exposed to $1,000 \mathrm{ppm}$ IAA emerged 2-4 d later than did controls (Table 4).

The mean longevity of IAA-treated adults decreased significantly at doses of 1,000 and 10,000 ppm $(\mathrm{F}=9.292 ; \mathrm{df}=5,354 ; \mathrm{P}=0.000)$ compared with lower doses tested and wasps reared on untreated hosts. Adults lived 30\% and $27 \%$ shorter lives than did controls at doses of 1,000 and 10,000 ppm, respectively (Table 4). All IAA-treated females except for those at 500 ppm lived shorter lives than did controls, however there was only a considerable decline in the longevity of females $(\mathrm{F}=8.901$; $\mathrm{df}=5$, $174 ; \mathrm{P}=0.001)$ at 1,000 and $10,000 \mathrm{ppm}$. The longevity of females declined by 28 and $33 \%$, respectively. Male longevity fluctuated among doses $(\mathrm{F}=4.160 ; \mathrm{df}=5,174 ; \mathrm{P}=0.001)$ with a significant decrease only at $1,000 \mathrm{ppm}$ such that males lived 33\% shorter lives than did controls (Table 4). 
Table 3

IAA-related changes in adult longevity, female sex ratio, adult weight and size of G. mellonella.

\begin{tabular}{|c|c|c|c|c|}
\hline IAA (ppm) & $\begin{array}{c}\text { Adult longevity (day) } \\
\text { Mean }{ }^{\mathrm{a}} \pm \mathrm{SE}^{\mathrm{b}}\end{array}$ & $\begin{array}{c}\text { Female sex ratio (\%) } \\
\text { Mean } \pm \mathrm{SE}^{\mathrm{b}}\end{array}$ & $\begin{array}{c}\text { Adult weight (g) } \\
\text { Mean }^{\mathrm{a}} \mathrm{SE}^{\mathrm{b}}\end{array}$ & $\begin{array}{c}\text { Adult size (mm) } \\
\text { Mean }^{\mathrm{a}} \pm \mathrm{SE}^{\mathrm{b}}\end{array}$ \\
\hline 0 & $22.49 \pm 1.29 \mathrm{a}$ & $86.66 \pm 6.67 \mathrm{a}$ & $0.09 \pm 0.00 \mathrm{a}$ & $12.32 \pm 0.19 \mathrm{ab}$ \\
50 & $18.73 \pm 0.96 \mathrm{a}$ & $93.33 \pm 6.67 \mathrm{a}$ & $0.09 \pm 0.00 \mathrm{a}$ & $12.39 \pm 0.17 \mathrm{ab}$ \\
500 & $19.42 \pm 0.89 \mathrm{a}$ & $88.89 \pm 5.88 \mathrm{a}$ & $0.07 \pm 0.00 \mathrm{~b}$ & $11.93 \pm 0.18 \mathrm{a}$ \\
1,000 & $20.38 \pm 0.93 \mathrm{a}$ & $68.89 \pm 8.01 \mathrm{a}$ & $0.08 \pm 0.00 \mathrm{a}$ & $12.61 \pm 0.20 \mathrm{ab}$ \\
5,000 & $22.07 \pm 1.13 \mathrm{a}$ & $84.44 \pm 4.44 \mathrm{a}$ & $0.08 \pm 0.00 \mathrm{ab}$ & $12.10 \pm 0.17 \mathrm{a}$ \\
10,000 & $18.73 \pm 1.39 \mathrm{a}$ & $73.33 \pm 6.67 \mathrm{a}$ & $0.09 \pm 0.00 \mathrm{a}$ & $12.88 \pm 0.16 \mathrm{~b}$ \\
\hline
\end{tabular}

a Means within each column followed by the same letter are not significantly different $(\mathrm{P}>0.05)$.

b Average of 45 individuals per treatment.

Treatment with IAA did not affect the adult weight of males $(\mathrm{F}=1.073$; df $=5,174 ; \mathrm{P}=$ $0.377)$ and both sexes combined $(\mathrm{F}=1.177$; df $=5,354 ; \mathrm{P}=0.177)$ when compared to controls. However, there was only a significant decrease in female weight at 5,000 ppm $(\mathrm{F}=2.676$; $\mathrm{df}=$
5, 174; $\mathrm{P}=0.023)$ when compared to 500 and 10,000 ppm (Table 5).

Adult wasp females reared on IAA-treated hosts did not differ in length $(\mathrm{F}=1.160 ; \mathrm{df}=5$, $174 ; \mathrm{P}=0.331$ ), while there were only significant

Table 4

IAA-related changes in immature developmental time and adult longevity of $P$. turionellae.

\begin{tabular}{|c|c|c|c|c|c|c|}
\hline & \multicolumn{2}{|c|}{ Immature Developmental Time (day) } & \multicolumn{3}{c|}{ Adult Longevity (day) } \\
\hline \multirow{2}{*}{$\mathrm{IAA}(\mathrm{ppm})$} & Female & Male & Both sexes & Female & Male & Both sexes \\
Mean $^{\mathrm{a}} \pm \mathrm{SE}^{\mathrm{b}}$ & Mean $^{\mathrm{a}} \pm \mathrm{SE}^{\mathrm{b}}$ & Mean $^{\mathrm{c}} \pm \mathrm{SE}^{\mathrm{b}}$ & Mean $^{\mathrm{a}} \pm \mathrm{SE}^{\mathrm{b}}$ & Mean $^{\mathrm{a}} \mathrm{SE}^{\mathrm{b}}$ & $\mathrm{Mean}^{\mathrm{c}} \pm \mathrm{SE}^{\mathrm{b}}$ \\
\hline 0 & $19.50 \pm 0.31 \mathrm{a}$ & $17.17 \pm 0.43 \mathrm{a}$ & $18.33 \pm 0.30 \mathrm{a}$ & $56.20 \pm 3.10 \mathrm{ab}$ & $42.10 \pm 2.24 \mathrm{~b}$ & $49.15 \pm 2.11 \mathrm{a}$ \\
50 & $19.50 \pm 0.27 \mathrm{a}$ & $17.97 \pm 0.30 \mathrm{ab}$ & $18.73 \pm 0.22 \mathrm{ab}$ & $55.60 \pm 2.88 \mathrm{ab}$ & $38.53 \pm 2.78 \mathrm{ab}$ & $47.07 \pm 2.27 \mathrm{a}$ \\
500 & $18.90 \pm 0.27 \mathrm{a}$ & $17.60 \pm 0.18 \mathrm{a}$ & $18.25 \pm 0.18 \mathrm{a}$ & $63.33 \pm 4.72 \mathrm{ab}$ & $41.20 \pm 3.53 \mathrm{~b}$ & $52.27 \pm 3.26 \mathrm{a}$ \\
1,000 & $19.93 \pm 0.30 \mathrm{a}$ & $19.13 \pm 0.38 \mathrm{~b}$ & $19.53 \pm 0.25 \mathrm{~b}$ & $40.70 \pm 2.59 \mathrm{~cd}$ & $28.03 \pm 2.09 \mathrm{a}$ & $34.37 \pm 1.85 \mathrm{~b}$ \\
5,000 & $19.80 \pm 0.35 \mathrm{a}$ & $18.53 \pm 0.36 \mathrm{ab}$ & $19.17 \pm 0.26 \mathrm{ab}$ & $54.17 \pm 3.99 \mathrm{bc}$ & $33.67 \pm 2.88 \mathrm{ab}$ & $43.92 \pm 2.78 \mathrm{ab}$ \\
10,000 & $19.50 \pm 0.31 \mathrm{a}$ & $17.17 \pm 0.43 \mathrm{ab}$ & $19.05 \pm 0.22 \mathrm{ab}$ & $37.73 \pm 2.87 \mathrm{~d}$ & $33.47 \pm 2.06 \mathrm{ab}$ & $35.60 \pm 1.77 \mathrm{~b}$ \\
\hline
\end{tabular}

a Means within each column followed by the same letter are not significantly different $(\mathrm{P}>0.05)$.

b Average of 30 individuals per treatment.

c Average of 60 individuals per treatment. 
Table 5

IAA-related changes in adult weight and adult size of $P$. turionellae.

\begin{tabular}{|c|c|c|c|c|c|c|}
\hline & \multicolumn{3}{|c|}{ Adult weight (g) } & \multicolumn{3}{c|}{ Adult size (mm) } \\
\hline \multirow{2}{*}{ IAA (ppm) } & $\begin{array}{c}\text { Female } \\
\text { Mean } \pm \mathrm{SE}^{\mathrm{b}}\end{array}$ & $\begin{array}{c}\text { Male } \\
\text { Mean } \pm \mathrm{SE}^{\mathrm{b}}\end{array}$ & $\begin{array}{c}\text { Both sexes } \\
\text { Meanc } \pm \mathrm{SE}^{\mathrm{b}}\end{array}$ & $\begin{array}{c}\text { Female } \\
\text { Mean } \pm \mathrm{SE}^{\mathrm{b}}\end{array}$ & $\begin{array}{c}\text { Male } \\
\text { Mean }^{\mathrm{a}} \pm \mathrm{SE}^{\mathrm{b}}\end{array}$ & $\begin{array}{c}\text { Both sexes } \\
\text { Mean }^{\mathrm{c}} \pm \mathrm{SE}^{\mathrm{b}}\end{array}$ \\
\hline 0 & $0.03 \pm 0.00 \mathrm{ab}$ & $0.02 \pm 0.00 \mathrm{a}$ & $0.02 \pm 0.00 \mathrm{a}$ & $10.82 \pm 0.18 \mathrm{a}$ & $9.87 \pm 0.15 \mathrm{ab}$ & $10.36 \pm 0.13 \mathrm{ab}$ \\
50 & $0.03 \pm 0.00 \mathrm{ab}$ & $0.02 \pm 0.00 \mathrm{a}$ & $0.02 \pm 0.00 \mathrm{a}$ & $10.52 \pm 0.15 \mathrm{a}$ & $9.85 \pm 0.22 \mathrm{ab}$ & $10.19 \pm 0.14 \mathrm{ab}$ \\
500 & $0.03 \pm 0.00 \mathrm{~b}$ & $0.02 \pm 0.00 \mathrm{a}$ & $0.03 \pm 0.00 \mathrm{a}$ & $11.00 \pm 0.15 \mathrm{a}$ & $10.35 \pm 0.19 \mathrm{~b}$ & $10.68 \pm 0.13 \mathrm{~b}$ \\
1,000 & $0.03 \pm 0.00 \mathrm{ab}$ & $0.02 \pm 0.00 \mathrm{a}$ & $0.02 \pm 0.00 \mathrm{a}$ & $10.602 \pm 0.18 \mathrm{a}$ & $9.42 \pm 0.19 \mathrm{a}$ & $10.01 \pm 0.15 \mathrm{a}$ \\
5,000 & $0.02 \pm 0.00 \mathrm{a}$ & $0.02 \pm 0.00 \mathrm{a}$ & $0.02 \pm 0.00 \mathrm{a}$ & $10.60 \pm 0.19 \mathrm{a}$ & $10.15 \pm 0.20 \mathrm{ab}$ & $10.38 \pm 0.14 \mathrm{ab}$ \\
10,000 & $0.03 \pm 0.00 \mathrm{~b}$ & $0.02 \pm 0.00 \mathrm{a}$ & $0.02 \pm 0.00 \mathrm{a}$ & $10.75 \pm 0.15 \mathrm{a}$ & $9.58 \pm 0.20 \mathrm{ab}$ & $10.17 \pm 0.14 \mathrm{a}$ \\
\hline
\end{tabular}

${ }^{a}$ Means within each column followed by the same letter are not significantly different $(\mathrm{P}>0.05)$.

b Average of 30 individuals per treatment.

c Average of 60 individuals per treatment.

variations among doses in males $(\mathrm{F}=3.183$; df $=5,174 ; \mathrm{P}=0.000)$ and both sexes combined $(\mathrm{F}$ $=2.724 ; \mathrm{df}=5,354 ; \mathrm{P}=0.020)$. However, IAA treatment also did not affect the size of males and both sexes combined when compared to that of controls (Table 5).

\section{DISCUSSION}

Previous studies have demonstrated that different PGRs influence the well-being of various insects differently, including pests (KAUR \& RUP, 2002; 2003a; 2003b; HARIKESH \& BHATTACHARYA, 2003; GUPTA et al. 2009) and those species that are beneficial (UÇKAN et al., 2008; UÇKAN et al., 2011a; b), and are considered as ecological life vests (UÇKAN \& GÜLEL, 2002). Here, we first attempted to explore the effects of IAA on the reproductive potential of the pest species, G. mellonella. Analysis of the data for the total number of eggs laid per female revealed that treatment with different IAA doses did not affect the reproductive potential of the pest species. Percent fecundity increased by $12 \%$ at $50 \mathrm{ppm}$ whereas the most effective decrease by $>33 \%$ was observed at 5,000 ppm. However, both results were not significantly different from that observed in controls. Percent fertility significantly decreased by $>20 \%$ at $1,000 \mathrm{ppm}$. Compatible with percent fertility, all treatments displayed $\pm 5 \%$ variations when compared to controls except for a significant increase in corrected percent sterility by $>20 \%$ at $1,000 \mathrm{ppm}$.

It is likely that IAA had a low level of adverse activity on the reproductive potential of $G$. mellonella. Similar responses have also been observed in B. cucurbitae (KAUR \& RUP, 2002) Dacus dorsalis (Hendel, 1912) (THAKUR \& KUMAR, 1984), Lipaphis erysimi (Kaltenbach, 1843) (Rup \& DHILlon, 1999) and Zaprionus paravittiger (Godbole \& Vaidya, 1972) (RUP et al., 1997). Researchers suggested that the impact of IAA may be correlated to its interference with the neurosecretory system, which may affect the reproductive system (THAKUR \& KUMAR 1984). Our observations may suggest that IAA does not have a lethal effect toward developing pest progeny across trophic levels. 
We previously demonstrated $\mathrm{GA}_{3}$ had consistent negative effects on the pre-adult developmental time of $G$. mellonella with $>35 \%$ reduction in overall time to adult eclosion largely due to the decrease in egg-larval developmental time at the highest dose of 5,000 ppm tested (UÇKAN et al., 2011b). However, this study with the same pest species did not find a considerable effect of IAA on the egg hatching, larval, pupal developmental and adult emergence times from treatments; rather, only slight increases in egg hatching and larval developmental times, decreases in pupal developmental time, and both in adult emergence time were recorded at some doses tested. The most striking effect observed was a decline in pupal developmental time of $G$. mellonella by $>47 \%$ at 1,000 and 10,000 ppm. GUPTA et al. (2009) reported that $\mathrm{GA}_{3}$ and siapton caused an increase in the larval period of the hairy caterpillar, S. oblique at high doses. Furthermore, KAUR \& RUP (1999) observed parallel responses in B. cucurbitae by using GA 3 However, GUPTA et al. (2009) reported that triacontanal (a saturated long chain alcohol that is known to have a growth promoting activity) did not cause any significant difference in larval or pupal period at any dose tested. Thus, the effects of plant growth regulators on insect pests are variable.

We have previously suggested that $\mathrm{GA}_{3}$ could be used as an insecticide against $G$. mellonella since treatment with $\mathrm{GA}_{3}$ in the diet resulted in a significant influence on the immature developmental time of the pest larva, which is considered the most damaging stage of the pest species (Uçkan et al., 2011b). Further evidence from that study that $\mathrm{GA}_{3}$ did not affect the eggto-adult developmental time of parasitoids also supports the assumption that $\mathrm{GA}_{3}$ would be a successful chemosterilant against pest species. However, in the present study, IAA had a relatively low level of adverse activity on the reproductive potential and immature developmental times and almost no effect was observed on adult longevity and female sex ratio of the pest species. The differences in adult size and weight were also significant at only some doses tested. On the other hand, we observed that IAA treatment caused a slight prolongation in adult emergence and decrease in adult longevity of parasitoids reared on hosts exposed to different doses; longevity of wasps declined by $>27 \%$ at higher doses. Our previous work also demonstrated that the egg to adult developmental time of the wasp A. galleriae reared on A. grisella larvae exposed to high doses ( $\geq 200 \mathrm{ppm}$ ) of GA increased by $40 \%$ (UÇKAN et al., 2008), and increased by $30 \%$ when wasps were reared on larvae exposed to $\geq 500 \mathrm{ppm}$ of IAA (UÇKAN et al., 2011a). Similar responses in the adult longevity of parasitoid wasps have also been observed as a decrease by $>50 \%$ when wasps were reared on hosts exposed to high doses of IAA and $\mathrm{GA}_{3}$ treatments (UÇKAN et al., 2008, 2011a). KAUR \& KAUR (2013) also observed decreased female life span and extended developmental periods of the braconid wasp $B$. hebetor reared on $S$. litura exposed to high doses of coumarin. These results are expected, because previous studies displayed that PGRs reduce the total lipid and carbohydrate levels in insects (RAUP et al., 1998; KAUR \& RUP 2003b). We have observed that lipid at all doses, and carbohydrate at most of the doses, decreased in the hemolymph of $G$. mellonella larvae upon exposure to $\mathrm{GA}_{3}$ (UÇKAN et al., 2011b). Recently, we also found that $\mathrm{GA}_{3}$ resulted in different effects on the quantity of free amino acids associated with energy metabolism of G. mellonella and P. turionellae (ALTUNTAŞ et al., 2014). It is known that stress responses in arthropods are energetically demanding events (KorsLOOT et al., 2004) and RUP et al. (2000, 2002) suggested that PGRs-induced stress may cause decreases in hemolymph components. It is likely that the decrease in energy reserves of the host resulting from IAA-induced stress may cause delay in the immature growth and development and a decline in adult longevity of parasitoid species (UÇKAN \& ERGIN 2002; UÇKAN et al., 2007, 2008). Thus, it may be concluded that PGRs influence the life history parameters of various insects differently, depending on a number of factors. In the present case, our data displayed no severe adverse effects on the reproductive potential, development and longevity of pest species, whereas interferences in development 
and longevity of wasps were abundant at high doses of IAA treatment. Further effects of IAA should be explored for its overall influence on pest status before proposing this plant growth factor as an environmentally-safe compound for use in the management of lepidopteran pest species. The authors are currently attempting to evaluate the effects of IAA on the hemolytic and phenoloxidase activity, hormones controlling insect development and metamorphosis, and antioxidant enzymes detoxifying free radicals of the pest species G. mellonella. In addition, investigation of how the same parameters are affected by IAA via host feeding for $P$. turionellae is with in the scope of new research.

\section{REFERENCES}

AHMAD N, RASHDI SMMS \& RAJPUT AA (2003). Efficacy of plant growth regulators to manage the insect pests of cotton. Asian Journal of Plant Sciences, 2:544-547.

AltunTAŞ H, KILIÇ AY, UÇKAN F \& ERGin E (2012). Effects of gibberellic acid on hemocytes of Galleria mellonella L. (Lepidoptera: Pyralidae). Environmental Entomology, 41 (3):688-696.

ALTUNTAŞ H, UÇKAN F, KILIÇ AY \& ERGin E (2014). Effects of gibberellic acid on hemolymph free amino acids of Galleria mellonella (Lepidoptera: Pyralidae) and Endoparasitoid Pimpla turionellae (Hymenoptera: Ichneumonidae). Annals of the Entomological Society of America, 107 (5):10001009.

BRONSKILL JF (1961). A cage to simplify the rearing of the greater wax moth, Galleria mellonella (Pyralidae). Journal of the Lepidoptera Society, 15:102-104.

DoutT RL (1955). Reviewed Biological Control of Agricultural Pests. The American Biology Teacher, 17(4):134-136.

ERGiN E, ER A, UÇKAN F \& Rivers DB (2007). Effects of cypermethrin exposed hosts on eggadult development time, number of offspring, sex ratio, longevity, and size of Apanteles galleriae Wilkinson (Hymenoptera: Braconidae). Belgian Journal of Zoology, 137:27-31.

FISHER R (1987). Ecological investigations on pupal parasitoids (Hym., Ichneumonidae) of four Yponomeuta species (Lepid., Yponomeutidae).
Journal of Applied Entomology, 103(1-5):515523.

GUPTA G, YADAV SR, BHATTACHARYA AK (2009). Influence of synthetic plant growth substances on the survivorship and developmental parameters of Spilarctia obliqua Walker (Lepidoptera: Arctiidae). Journal of Pesticide Science, 82:41-46.

HAESElbarth E (1979). On the pupal parasites of the Pine Beauty (Panolis flammea (Schiff.)), the Pine Looper (Bupalus piniarius (L.)) and of Boarmia bistortata (Goeze) in Bavarian pine forests. Zeitschrift für Angewandte Entomologie, 87(3):186-202.

HARIKESH S, BHATTACHARYA AK (2003). Negative role of gibberellic acid on the developmental behaviour of Spodoptera litura. Indian Journal of Entomology, 65: 293-297.

KANSU IA \& UĞUR A (1984). Investigations into the biological relationships between Pimpla turionellae (L.) (Hymenoptera - Ichneumonidae) and some lepidopterous pupae hosts. Doğa Bilim Dergisi, 8(2):160-173.

KAUR M \& KAUR S (2013). Tritrophic interactions among coumarin, the herbivore Spodoptera litura and a gregarious ectoparasitoid Bracon hebetor. BioControl, 58:755-763.

KAUR R \& RUP PJ (1999). Evaluation of gibberellic acid against immature stages of Bactrocera cucurbitae (Coquillett). Journal of Insect Science, 12:9-14.

KAUR R \& RUP PJ (2002). Evaluation of regulatory influence of four plant growth regulators on the reproductive potential and longevity of melon fruit fly Bactrocera cucurbitae. Phytoparasitica, 30:224-230.

KAUR R \& RUP PJ (2003a). Influence of four plant growth regulators on development of the melon fruit fly, Bactrocera cucurbitae (Coquillett). Insect Science and Its Application, 23:121-125.

KAUR R \& RUP PJ (2003b). Influence of some plant growth regulators (PGR) on biochemical profile in the larvae of melon fruit fly Bactrocera cucurbitae (Coquillett) (Diptera: Trypetidae). Entomon, 28:89-95.

Korsloot A, VAN Gestel CAM \& VAN STRAALEN NM (2004). Environmental stress and cellular response in arthropods. CRC press, Boca Raton, Florida.

PAulson GS, Hull LA \& Biddinger DJ (2005). Effect of a plant growth regulator prohexadione- 
calcium on insect pests of apple and pear. Journal of Economic Entomology, 98:423-431.

PRADO SG \& FRANK SD (2013). Tritrophic effects of plant growth regulators in an aphid-parasitoid system. Biological Control, 66:72-76.

RUP PJ \& DHILlON MK (1999). Morphogenetic and biochemical responses of the mustard aphid, Lipaphis erysimi (Kalt.) (Homoptera: Aphididae) to indole-3-acetic acid (IAA). Journal of Aphidology, 13:31-38.

RUP PJ \& KALIA S (1993). Effect of gibberellic acid on the development of banana fruit fly, Zaprionus paravittiger (Godbole and Vaidya) (Drosophilidae: Diptera). Pest Management and Economic Zoology, 1:27-31.

RUP PJ, KAUR R \& KAUR J (1998). Effect of gibberellic acid (GA3) on the protein, lipid and carbohydrate contents of banana fruit fly, Zaprionus paravittiger larvae. Insect Science and Its Application, 18:145-148.

RUPPJ,KUMARIS\&SOHALSK(1997). Morphogenetic responses of Zaprionus paravittiger to indole acetic acid. In: GROVER IS \& THUKRAL AS (eds) Environment and Development. Scientific Publishers, Jodhpur, India:289-293.

Rup PJ, SOHAL SK, KaUR G \& DHILlON M (2002). The influence of allelochemicals and plant growth regulators on emergence and development of mustard aphid, Lipaphis erysimi (Kalt.). Allelopathy Journal, 10:53-58.

Rup PJ, Sohal SK, Sohi R, KaUR G, SANDhU N, GuRM SK, DHINGRA P \& WADHWA SK (2000). Influence of PGRs on carbohydrate content in Lipaphis erysimi (Kalt.). Indian Journal of Experimental Biology, 38:1066-1068.

SAK O, UÇKAN F \& ERGİN E (2006). Effects of cypermethrin on total body weight, glycogen, protein, and lipid contents of Pimpla turionellae (L.) (Hymenoptera: Ichneumonidae). Belgian Journal of Zoology, 136:53-58.

SALAMA HS \& El-SHARABY AM (1972). Gibberellic acid and $\beta$-sitosterol as sterilants of the cotton leafworm, Spodoptera littoralis Boisduval (Lepidoptera: Noctuidae). Experientia, 28:413-414.

SANFORD MT (1987). Diseases and Pests of the Honey Bee. University of Florida Cooperative Extension Service, Institute of Food and Agriculture Sciences, EDIS.

SLANSKY JRF (1986). Nutritional ecology of endoparasitic insects and their hosts: an overview. Journal of Insect Physiology, 32(4):255-261.
TANAKA T \& MINAKUCHI C (2012). Insecticides and Parasitoids. In: PERVEen F (ed.) Insecticides Advances in Integrated Pest Management. InTech: 115-140. (ISBN: 978-953-307-780-2)

THAKUR JN \& KUMAR A (1984). Effects of 3-indole acetic acid on the fertility of fruit fly, Dacus dorsalis Hendel (Diptera: Tephritidae). National Academy Science Letters India, 7:197-199.

UÇKAN F \& ERGİN E (2002). Effect of host diet on the immature developmental time, fecundity, sex ratio, adult longevity, and size of Apanteles galleriae (Hymenoptera: Braconidae). Environmental Entomology, 31:168-171.

UÇKAN F \& GÜLEL A (2002). Age-related fecundity and sex ratio variation in Apanteles galleriae (Hym., Braconidae) and host effect on fecundity and sex ratio of its hyperparasitoid Dibrachys boarmiae (Hym., Pteromalidae). Journal of Applied Entomology, 126:534-537.

UÇKAN F, HEPÇORMAN ŞENGÜl Ş, SAK O \& KORKMAZ M (2007). Effects of 5-aza-dC on biological parameters of the larval endoparasitoid Apanteles galleriae (Hymenoptera: Braconidae), and on its host, Achoria grisella (Lepidoptera: Pyralidae). Annals of the Entomological Society of America, 100:265-269.

UÇKAN F, HAFTACI İ \& ERGİN E (2011a) Effects of indol-3-acetic acid on biological parameters of the larval endoparasitoid Apanteles galleriae (Hymenoptera: Braconidae). Annals of the Entomological Society of America, 104(1):77-82.

UÇKAN F, ÖZTÜRK Z, ALtUNTAŞ H \& ERGİN E (2011b). Effects of gibberellic acid (GA3) on biological parameters and hemolymph metabolites of the pupal endoparasitoid Pimpla turionellae (Hymenoptera: Ichneumonidae) and its host Galleria mellonella (Lepidoptera: Pyralidae). Journal of the Entomological Research Society, 13(3):1-14.

UÇKAN F, TÜVEN A, ER A \& ERGİN E (2008). Effects of gibberellic acid on biological parameters of the larval endoparasitoid Apanteles galleriae (Hymenoptera: Braconidae). Annals of the Entomological Society of America, 101:593-597.

Received: July 14th, 2014

Accepted: February 8th, 2015

Branch editor: Guy Smagghe 